\title{
The world's largest refugee camp prepares for covid-19
}

Nearly a million refugees live in overcrowded conditions in the camps of south Bangladesh. Gaia Vince reports on the growing fears of an imminent, catastrophic outbreak of covid-19

\section{Gaia Vince science journalist and author}

London, UK

Bangladesh, with its 168 million inhabitants, is one of the poorest and most densely populated countries in the world. Millions live cheek by jowl in slums, where 10 or more households share a toilet. People move around the country on packed buses, and still throng to markets and mosques. Last week, for instance, tens of thousands gathered in a field to pray for an end to covid-19.

On 26 March the government imposed a lockdown, including banning public transport, in a bid to combat the growing pandemic, although hundreds of workers have been crowding onto private vehicles, such as trucks, instead. Bangladesh has seen the number of confirmed cases of covid-19 rise above 39, with four known deaths. The south Asian nation responded earlier in March by banning flights, shutting down schools, and promoting hygiene and social distancing measures. With very limited testing, however, and only in the capital, Dhaka, the true number of cases is expected to be far higher, and the low income nation's capacity to treat critically ill patients is limited.

And there's one further factor-the overcrowded conditions of the world's biggest refugee camp, located in Cox's Bazar in the far south east of Bangladesh.

The second poorest district in the country, Cox's Bazar is home to over 855000 Rohingya refugees from neighbouring Myanmar (former Burma), as well as visiting aid workers. ${ }^{1}$

The refugees are survivors of a massacre, carried out by Myanmar's military, of the country's minority Muslim population. The refugees live on a hastily deforested hillside, with families, densely packed, sleeping on mats in one room shacks made from plastic woven walls and roofed with plastic sheets. The enormous, crowded "city" of shacks, that stretches as far as the eye can see, is served by few latrines and freshwater standpipes, and consequently many of the pathways run thick with sewage.

Maintaining basic hygiene is hard enough but striving for the increased coronavirus protection measures recommended by WHO seems Herculean. And yet, that's what's being attempted.

The United Nations High Commission for Refugees (UNHCR) is helping to coordinate efforts to increase hand washing at the site. "We've been working with partners for the past two weeks to install portable hand washing facilities at every community centre throughout the camps. We've made a good start, but this is ongoing," Louise Donovan of UNHCR, who is based in Cox's Bazar, told The BMJ.

"We're also developing a managed roll-out of information in the three languages spoken in the camp-Rohingya, Bengali, and Chittagonian - to communicate WHO public guidance on handwashing frequently and thoroughly with soap and water, protecting coughs with an elbow, sneezing into a tissue, and so on," she added. Aid workers are training trainers to take these messages throughout the camps, using community leaders, such as imams and women's group leaders, to deliver the advice in a trusted way.

"People are generally apprehensive and worried about the virus," Donovan said. "This is true everywhere in the country but particularly in the camps. Rumours spread easily."

The aid workers have built up invaluable experience in communicating health advice and dealing with disease outbreaks over the past two and a half years, including the outbreaks of mosquitoborne infections such as malaria and dengue that occur with monsoons, and incidents of highly contagious bacterial infections, such as diphtheria and cholera. As a result, Donovan says, agency workers are generally seen as a credible, trustworthy source when people reach out for accurate information. "It's amazing to watch the self-mobilisation of people helping to spread the messages through social media."

Handwashing measures can only go so far to reduce spread of the virus once it enters the camp, though. Physical distancing, while an effective intervention elsewhere in the world, seems impossible in such crowded living conditions. Nevertheless, gatherings are being discouraged.

On 16 March, the Bangladesh government closed all schools, including the camp's learning centres and community centres. This is a particular blow because the camp's children have been denied any formal education because of government restrictions-these were to be lifted in April, allowing 10000 children aged 11-13 access to schooling for the first time. "We've learnt from past outbreaks how important it is for agencies to coordinate efforts with government," Donovan said. 
"One of the most important advocacy jobs is making sure that refugees - the most vulnerable populations-are included in national decisions and measures and not seen as a separate group or ignored."

The refugees, who have neither Myanmar nor Bangladeshi citizenship, are effectively imprisoned with each other. It means that aid workers-who enter and leave the camp daily-would be the most likely vectors or sources of covid-19. At the time of writing, Bangladeshi rules state that everyone entering the country is advised to self-quarantine for 14 days, and Europeans can't enter at all unless they hold diplomatic passes or are Bangladeshi residents. There are also fever scanners at the airports, including at Cox's Bazar, although these only detect people with symptoms of the virus, and not those who have yet to show symptoms or who are asymptomatic.

Many fear that an outbreak in the camp is likely, and aid agencies are readying themselves. "In some ways, we are prepared. We've learnt how to respond rapidly to outbreaks, to provide financial resources for protective equipment, for instance, and to ensure that access to food, sanitation, and other healthcare continues through a crisis," Donovan says.

Isolation units are being established. "If someone is not feeling well and presenting with covid-19 symptoms, they will be moved into an isolation zone in the community, and then transported to an isolation unit."

More than half of the refugees in the camp are children, and data from China and other affected nations indicate that the mortality rate for covid-19 is lowest for this demographic-to date there are no reported deaths from the virus in children under 10. Children in the camps, however, are malnourished and frequently stricken with diarrhoea and respiratory infections, making them more vulnerable. And evidence suggests that children, while frequently symptomless, can still infect others. ${ }^{2}$

Currently there is no mechanism to test refugees for covid-19-the only testing facilities are in Dhaka, $400 \mathrm{~km}$ away-and without testing, it is difficult to contain the first few cases of an outbreak. According to WHO in Dhaka, however, Bangladesh is currently scaling up testing capacities with new laboratories across the country expected to start testing soon.

"Covid-19 tests and reagents have been already distributed and additional tests are currently imported or are received as donations from supporting countries," Catalin Bercaru of WHO, based in Dhaka, told The BMJ. "The Institute of Epidemiology, Disease Control, and Research field laboratory in Cox's Bazar is currently being assessed to be included in the country's network of testing facilities."

During the week of 16 March, an international cohort of experts warned that developing countries risk missing out on key protective equipment, testing reagents, treatments, and vaccines. "The problem is that low income countries are probably arriving on the third wave, after China, after Europe. Access to tests is going to be problematic," Karl Blanchet, director of the Geneva based Centre for Education and Research in Humanitarian Action said in a "webinar" hosted by the New Humanitarian news agency.

The humanitarian community may have to change tack and invest in strengthening worldwide public health systems rather than focusing on single matter campaigns. "This is not just about providing services in a refugee site or a conflict affected area, this is really about health systems and health seeking and health protecting behaviour across entire countries," Jeremy Konyndyk, senior policy fellow at the Center for Global Development in Washington, DC, said in the webinar.

In Cox's Bazar, aid workers are already deeply embedded in the local host community as well as the refugee camps and have worked hard to coordinate their efforts with national and local government agencies over the past two and a half years. It's produced goodwill and bravery in this anxious time. "We have responders ready to act," says Donovan. But unlike past humanitarian disasters, this one is global. "The international workers have family overseas that they're worried about too.”

Competing interests: I have read and understood BMJ policy on declaration of interests and have no relevant interests to declare.

1 Vince G. How to survive in the world's biggest refugee camp. Mosaic. 2019. https:// mosaicscience.com/story/how-survive-worlds-largest-refugee-camp.

2 Dong Y, Mo X, Hu Y, et al. Epidemiology of COVID-19 among children in China. American Academy of Pediatrics. 2020. https://pediatrics.aappublications.org/content/pediatrics/ early/2020/03/16/peds.2020-0702.full.pdf.

Published by the BMJ Publishing Group Limited. For permission to use (where not already granted under a licence) please go to http://group.bmj.com/group/rights-licensing/ permissions 